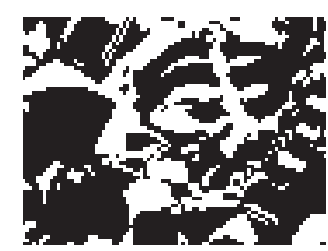

\title{
DO GOVERNMENTAL SUBSIDIES INCREASE PRODUCTIVITY OF FIRMS? EVIDENCE FROM A PANEL OF SLOVENE FIRMS
}

Polona DOMADENIK, Matjaž KOMAN, Janez PRAŠNIKAR Faculty of Economics, Ljubliana

UDK: 338.246.027(497.4)"1998/2012"

$336.13(497.4)^{\prime \prime} 1998 / 2012^{\prime \prime}$

338.242.4(497.4)"1998/2012"

Izvorni znanstveni rad

Primlieno: 5. 9. 2015.

Our study focuses on examining the relationship between productivity (or productivity growth) and state aid allocation in Slovenia during the period of 1998 to 2012. The country itself represents almost an ideal case as the amount of subsidies being allocated in the relevant period decreased significantly after joining the EU. Our study builds on the theoretical model of Aghion et al. (2015) arguing that sectorial policy can enhance growth and efficiency if it is made competition-friendly. The main results show, that by increasing dispersion of subsidies within particular sectors by one standard deviation, the productivity growth increases by 0.03 percentage points on average, ceteris paribus. State aid has been especially important in the period of economic downturn (2009-2012). However we found evidence that firms receiving a higher portion of subsidies were less productive when compared with counterparts from the same sector receiving less or no subsidies. The difference was the biggest during the period of economic downturn.

Keywords: state aid, subsidies, industrial policy, competition

$\bowtie \quad$ Matjaž Koman, Faculty of Economics, University of Ljubljana, Kardeljeva ploščad 17, 1000 Ljubljana, Slovenia. 
Does industrial policy contribute to higher or lower productivity of firms? Do industrial policy measures distort competition? The discussion on the appropriateness of governmental policies directed at affecting the economic structure of the economy (often referred to as industrial policy) has been at the center of theoretical and empirical studies since the end of the Second World War. During this period some countries applied import substitution policies and regained focus during the Great Recession when governments around the world highly subsidized private firms mostly in the financial sector, automotive industry, IT and infrastructure (Bole, Gazibarić, Hrastel, Korelc, \& Prašnikar, 2014).

The rationale for this policy in the fifties was built on the idea that new infant industries and other local traditional activities should be protected from foreign competition and fully benefit from domestic demand (Aghion et al., 2015). Countries that followed this principle of industrial policy (Japan, Korea and Singapore are the most prominent examples in past decades) recorded outstanding growth rates as it was believed that these measures contribute to a nation's economic strength. However, in the seventies, when some bad examples of these policies were recorded, ${ }^{1}$ skepticism about the role of industrial policy increased and a significant body of academic literature started to criticize industry policy based mostly on the following two arguments: The first argument highlights that industry policy is based on the idea that government picks future winners in a discretionary fashion and hence opens the door to vested interests. The second important argument relates to the fact that in particular circumstances the government introduces measures to help firms in difficulty thereby inducing the well-known problem of soft budget constraint ${ }^{2}$ (Spector, Chapsal, \& Eymard, 2009). Based on the standard argument of market efficiency, the opponents of state intervention highlight that there is no need for the government to intervene either in the sectoral allocation of resources or the choices of technique.

In the last decade, the debate on subsidies has re-emerged, mostly being initiated by increasing awareness of climate change and the need to support and encourage development of alternative technologies in the field of environmental protection (Aghion, Boulanger, \& Cohen, 2011). Without government support it is not possible to have clean innovation, its application in production and households that generates high social but low private returns in the short run. Moreover, the recent financial crisis that motivated countries around the globe to provide support for particular industries or employment subsidies (horizontal measures to preserve employ- 
DRUŠ. ISTRAŽ. ZAGREB GOD. 27 (2018), BR. 2, STR. $199-220$

DOMADENIK, P., KOMAN M., PRAŠNIKAR, J.: DO GOVERNMENTAL... ment) and overcome financial constraints does pose a serious question as to whether this type of state aid policy leads to positive results. The crisis showed that markets were not necessarily efficient and, indeed, there was a broad consensus that without strong government intervention - which includes lifelines to certain firms and certain industries - many developed economies in Europe and the US may have collapsed (Stiglitz \& Greenwald, 2014).

Sparse econometric evidence on the efficiency of industrial policy contributes to the consensus among economists that industrial policy usually fails. Many of these policies, however, targeted firms and industries that would be in difficulties in the absence of the program, so ordinary least squares (OLS) estimates may miss any positive effects (Rodrik, 2007). Criscuolo, Martin, Overman, and Van Reenen (2016) studied business support policies in the UK after 2004 and found that areas eligible to state aid create significantly more jobs. Treatment effect exists solely for small firms as large companies obviously "game" the system and accept subsidies without changing their behavior. Based on rigorous modelling and testing, the research reported positive effect on net entry of new firms and firm investment but no effect on total factor productivity. Their findings are in line with Aghion et al. (2015) which shows that the debate on industrial policy should no longer be in the context of whether to have it or not but rather how such policies ought to be designed and governed to foster growth and welfare.

Our study contributes to an emerging literature on the causal impact of state subsidies and relates to a broader literature concerning evaluations of business support policies in at least two important aspects. First, it deals with a complete set of data on subsidies being granted in a relatively long time span (1998-2012) to firms in manufacturing and service sectors. To our knowledge, this is the first study on policy evaluation utilizing such detailed dataset. Second, the recent financial crises motivated several governments (USA, China, Australia among others) to provide support to specific industries and increase subsidies to the business sector much more if compared with the EU, although several studies that studied the effect of research subsidies on industrial R\&D found mixed evidence (Takalo, Tanayama, \& Toivanen, 2013; Einiö, 2014). Howell (2015) and Bronzini and Iachini (2014), on the other hand, used regression discontinuity design to assess the causal effects of direct grants and highlight the much larger positive effects on investment in small firms. Our study therefore provides additional evidence on the effectiveness of subsidies along the business cycle. 
DRUŠ. ISTRAŽ. ZAGREB GOD. 27 (2018), BR. 2, STR. 199-220

DOMADENIK, P., KOMAN, M., PRAŠNIKAR, J.: DO GOVERNMENTAL...
Slovenia represents almost an ideal case as the amount of subsidies being allocated in the studied period decreased significantly after joining the EU. The country went through a relatively successful transition from communism to a market economy in the 1990s and it entered the European Union in 2004 after adopting the European institutional framework and satisfying the Maastricht criteria for entering the European Monetary Union (EMU). In the first decade of transition Slovenia struggled with underdeveloped democratic institutions and a high degree of state ownership in large firms. Slovenia allocated between 1.42 (in year 2002) and 2.53 (in year 1998) percent of GDP in the form of state aid during the period of 1998-2002 before becoming an EU Member State. As EU member states, in principle, are not allowed to provide state aids as it could distort competition by favoring certain undertakings or the production of certain goods, state aid in Slovenia dropped to 1.58 percent of GDP in 2003 and a mere 0.87 percent in 2008.

Our main results show that productivity growth increases by 0.03 percentage points on average, ceteris paribus, when dispersion of subsidies is increased within particular industries by one standard deviation.

The study proceeds as follows. The second part describes the institutional framework of the state aid system in Slovenia and outlines how eligibility changes over time. Our empirical model is outlined in section three being followed by econometric issues and the presentation of data and sample. In section six we outline the results and conclude in the last section.

\section{INSTITUTIONAL FRAMEWORK:}

\section{STATE AID SYSTEM IN SLOVENIA FOR THE PERIOD 1998-2012}

Since the collapse of the self-management economic system, state aid came about to deal with the various problems regarding existing business models and privatization. Before 1998, the economic system was fragmented without any reliable data on scope or final beneficiaries. Interestingly, the amount of state aid allocated to agriculture and fishery almost doubled during this period at the expense of subsidies being directed to firms. In 19981.34 percent of GDP was allocated as horizontal aid (aid with horizontal objectives not being related either with regional or sectoral characteristics) in order to support R\&D, environmental investment, small and medium enterprises, employment or training, in general. The majority of horizontal state aid was given to exporting companies (Kovač, Breg, Rudl, Volf, \& Vuga, 2014). On the other hand, 0.65 percent was allocated directly to specific sectors (steel industry, trans- 
DRUŠ. ISTRAŽ. ZAGREB GOD. 27 (2018), BR. 2, STR. 199-220

DOMADENIK, P., KOMAN M., PRAŠNIKAR, J.: DO GOVERNMENTAL... portation, mining and others) in order to overcome the financial difficulties of firms operating in these sectors and to postpone bankruptcies. Both types of aid decreased significantly by 2002 to only one fourth for both types of state aid.

In 2001 the government launched a new program of measures for supporting competitiveness of the Slovene economy in the period 2002-2006, which significantly redefined the eligibility of the state aid system. Moreover, in 2004 Slovenia became an EU member state and had to comply with EU legislation. In principle, EU Member States are not allowed to provide state aids as it could distort competition by favoring certain undertakings or the production of certain goods. However, under Article 107 of the Lisbon Treaty, the EU allows exemptions if special conditions are being met. ${ }^{3}$ EU State aid control requires prior notification of all new aid measures to the Commission. Before putting the measure into effect, Member States need to obtain the Commission's approval. There are a few exceptions to mandatory notification such as aid covered by Block Exemption (a range of aid measures defined by the Commission), "de minimis" aid or other aid granted under the scheme already authorized by the Commission. ${ }^{4}$ The state aid regulation doesn't apply to aid for fisheries and agriculture, export related activities or firms in difficulty, among others.

In 2003 state aid still amounted to 1.58 percent of GDP in total (0.88 percent if excluding agriculture and fisheries), but significantly decreased to a mere 0.87 percent in 2008 (0.58 percent if excluding agriculture and fisheries). In 20030.49 percent of GDP was allocated as horizontal aid and dropped to 0.20 percent in 2008 , while 0.32 percent represented the aid to special sectors in 2003 and dropped by half ( 0.16 percent) five years later. The only part of state aid with an upward trend was regional aid that increased by almost 6 times in nominal terms in the period of 2003-2008 (Cepec, Beširević, Černe, Golle, \& Jelen, 2014).

The global financial crises dramatically changed the perception of governments regarding state aid to financial and non-financial entities. The state aid increased from 0.87 percent in 2008 to 2.9 percent in 2012. In 2009 one third of 1.9 percent of state aid ended up in the banking system, while in 2012 the proportion increased to almost 50 percent. When observing figures for horizontal measures (excluding special crisis measures), the aid amounted to 0.76 percent in 2009 and 1.1 percent in 2012. The most important measures related to R\&D support (increased from 21.61 million EUR in 2008 to 97.19 million EUR in 2010) and employment (from almost non-existent to almost 80 million EUR in 2012). However, this increase 
(4) FIGURE

The share of state aid to nonfinancial and financial sectors as a percentage of GDP in Slovenia for the period 1998-2012 was similar as in other EU countries and therefore substantially smaller compared to USA, Australia or China. (See Bole et al., 2014, for more details.) In Figure 1 we show the state aid in Slovenia to nonfinancial and financial sectors as a percentage of GDP.

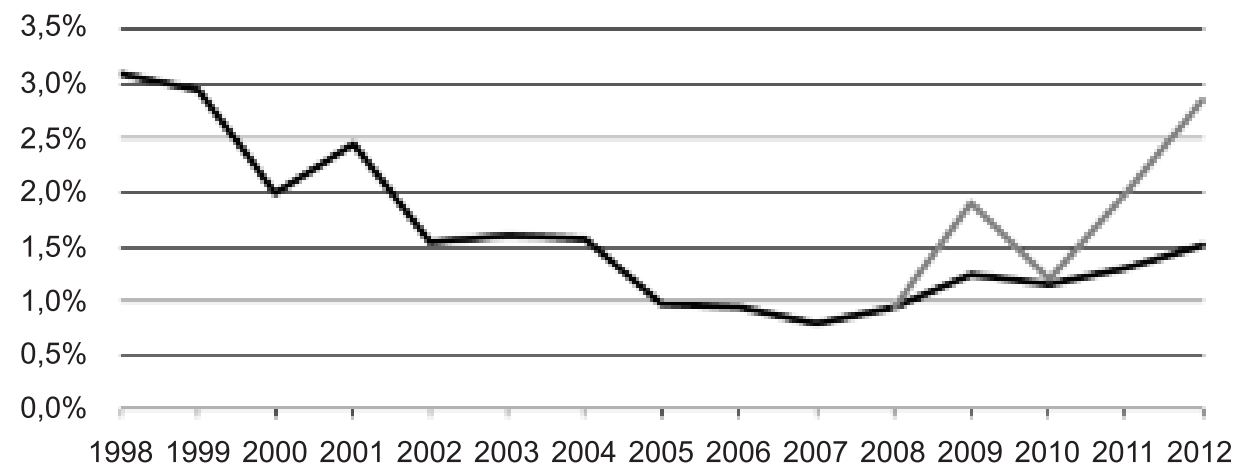

The share of state aid in GDP without crisis measures

The share of state aid in GDP if we also include crisis measures

Source: Ministry of Finance (2013).

\section{EMPIRICAL SPECIFICATION AND ECONOMETRIC ISSUES}

The most controversial issue in studying the effectiveness of state aid is whether positive effects (if any) come at the cost of lowering competition in the short run that is not sustainable in the long run. The consensus among the economists is that state aid usually fails to enhance productivity at the firm level although the econometric evidence is rare.

As illustrated in two similar studies by Nunn and Trefler (2010) and Aghion et al. (2015), industrial policy in the form of targeting in fact increases competition and also initiates increases in consumer surplus and growth. Nunn and Trefler (2010) used cross-country industry-level panel data to analyze whether the growth of productivity in a country is positively affected by the measure in which tariff protection is biased in favor of activities and sectors that are "skill-intensive", i.e., that use skilled workers more intensely. ${ }^{5}$ They find a significant positive correlation between productivity growth and the "skill bias" due to tariff protection with at least 25 percent of the correlation due to a causal effect. Overall, their analysis suggests that adequately designed (here, skill-intensive) targeting may actually enhance growth, not only in the sector which is being subsidized, but in other sectors as well. The Aghion et al. study (2015), on the other hand, was more general and argued 
that sectoral state aids tend to foster productivity growth and product innovation to a larger extent when policy targets more competitive sectors and is not concentrated on one or a small number of firms ("winners") in the sector.

\section{Empirical model}

Our empirical model builds on the work of Aghion et al. (2015) suggesting that targeting is more likely to be growth-enhancing when competition is more intense within a sector or when competition is preserved or increased by sectoral policy. Their theoretical approach is based on a two-period model of an economy producing two goods (A and B) in one of two "big" firms or by "fringe" firms. Big firms are the only firms in the market that can innovate. Innovation reduces production costs at different rates in two sectors. Under laissez-faire, firms can choose the technology based on which they want to produce (A or B) and a planner might induce such chosen technology. If the planner takes no action (laissez-faire), the reactions of two big firms might lead to different technology choices by the two firms (diversification) or the same choice (focus). Planner enforced action - targeting - would lead to focus (same choice). Comparing equilibrium innovation rates (the proxy for growth in this model) under diversity and focus, the latter leads to a higher innovation rate due to a sufficiently high degree of competition within the sectors. This in turn yields one of their main empirical predictions. Namely, government intervention inducing several firms to focus on the same activity is more growth enhancing the higher the degree of within sector product market competition.

To test this empirical prediction, Aghion et al. (2015) developed measures of targeting, competition, and outcomes. In order to capture the allocation of subsidies in such a way that preserves or increases competition, we follow their approach. As a measure of sectoral dispersion, we use the Herfindahl index constructed using the share of subsidies each firm $i$ in a given sector receives relative to the total subsidies awarded to the sector $j$ (HERF_subsidyjt). This serves as a measure of subsidies' concentration. ${ }^{6}$ A smaller Herfindahl index indicates a higher degree of dispersion of subsidies or a more competition-preserving allocation of subsidies across firms in the sector. In order to capture the degree of sectoral dispersion, we take the inverse of Herfindahl index - COMPHERF_subsidy. If allocation of subsidies were to induce greater focus by encouraging more firms to innovate within a specific sector, we would expect a positive coefficient on that variable in our regression.

To measure competition, we compute a Lerner index at the sector level $\left(C O M P_{j t}\right)$ which measures the importance of 
DRUŠ. ISTRAŽ. ZAGREB GOD. 27 (2018), BR. 2, STR. 199-220

DOMADENIK, P., KOMAN M., PRAŠNIKAR, J.: DO GOVERNMENTAL. markup relative to the firm's total value added. The outcome is usually measured by using total factor productivity (TFP $i t)$ and assuming that the production function of an individual firm may be approximated by a Cobb-Douglas form in a standard way (e.g., Acemoglu, 2009 and Jones, 1998) as:

$$
Y_{i t}=A_{t} K_{i t}^{\alpha}{ }^{\alpha}{ }^{2}{ }^{\beta},
$$

where $Y_{i t}$ represents output of firm $i$ in period $t, K t$ and $L t$ are capital and labor inputs, respectively, and $A_{t}$ is the Hicks-neutral efficiency level, or total factor productivity (TFP), of firm $i$ in period $t$. While $Y_{i t}, K_{i t}$ and $L i t$ are observable (usually in terms of value rather than in quantities), Ait is unobservable and is usually inferred as a residual. In this context, our test of whether receiving subsidies and allocation affect TFP at the firm level may be interpreted as a test of the effect of state aids on the ability of firms to generate competitive advantages.

The basic estimating equation can be written as follows:

$$
\begin{aligned}
& \mathrm{y}_{\mathrm{it}}=\alpha_{0}+\alpha_{1} k_{i t}+\alpha_{2} l_{i t}+\alpha_{3} \mathrm{~S}_{\mathrm{jt}}+\alpha_{4} \text { COMPHERF_subsidy }{ }_{j t}+ \\
& \alpha_{5} \text { Ratio_subsidy }_{\mathrm{it}}+\alpha_{6} \text { COMP }_{\mathrm{jt}}+\alpha_{7} \text { LOSS }_{\mathrm{it}}+\alpha_{8} \text { 'SEAR }_{\mathrm{t}}+ \\
& \alpha_{\mathrm{i}}+\mathrm{u}_{\mathrm{it}}
\end{aligned}
$$

where lower case letters correspond to the natural logarithms of variables in equation (1), except for yit that corresponds to value added of firm $i$ in period $t$, and $S$ represents sector-level controls. In order to identify the effect of subsidy on productivity of the firm while controlling dispersion of subsidies, concentration and firm level characteristics, we add another variable, Ratio_subsidyit, defined as the amount of subsidy divided by sales in individual firm $i$. We add an additional firm-level control for poor accounting results (dummy indicating whether zero or negative profits were reported) LOSSit, while YEAR is a vector of dummy variables capturing annual time effects. The specification includes firms' fixed effects $\alpha$.

In terms of our conceptual framework, equation (2) permits us to test the core hypotheses about the effect of state aid and its distribution on productivity of the firms:

H1: More dispersed subsidies (better targeting) at the sectoral level, ceteris paribus,

a) decreases total factor productivity in the short run $(\alpha 4<0)$,

$b)$ doesn't have any effect on total factor productivity in the short $\operatorname{run}\left(\alpha_{4}=0\right)$, or

c) increases total factor productivity in the short run $(\alpha 4>0)$.

$\mathrm{H} 2$ : Firms that receive more state aid, ceteris paribus, exhibit

a) lower total factor productivity in the short run $\left(\alpha_{5}<0\right)$,

b) same total factor productivity in the short run $\left(\alpha_{5}=0\right)$, or

c) higher total factor productivity in the short run $\left(\alpha_{5}>0\right)$. 
DRUŠ. ISTRAŽ. ZAGREB GOD. 27 (2018), BR. 2 STR. 199-220

DOMADENIK, P., KOMAN, M., PRAŠNIKAR, J.: DO GOVERNMENTAL..
Alternatively, we can specify the model in two steps with calculating total factor productivity (TFP) as the residual of the production function $\alpha_{0}(1 \mathrm{a})$ and regress in the second step on explanatory variables.

$$
\begin{aligned}
& \operatorname{lnTFP}{ }_{\mathrm{it}}=\beta_{1} \mathrm{~S}_{\mathrm{jt}}+\beta_{2} \text { COMPHERF_subsidy }_{j \mathrm{t}}+\beta_{3} \text { Ratio_subsidy }_{\mathrm{it}} \\
& +\beta_{4} \mathrm{COMP}_{\mathrm{jt}}+\beta_{5} \text { LOSS }_{\mathrm{it}}+\beta_{6}{ }^{\prime} \mathrm{YEAR}_{\mathrm{t}}+\alpha_{\mathrm{i}}+\mathrm{u}_{\mathrm{it}}
\end{aligned}
$$

Our parameters of interest are $\beta_{2}$ and $\beta_{3}$. The advantages and shortcomings of both specifications (2) and (3) will be presented in the next section.

\section{Econometric issues}

The identification and estimation of production functions using data on inputs and output is among the oldest empirical problems in economics with a key challenge of identification arising from the endogeneity of inputs (the transmission bias discussed for instance by Griliches and Mairesse, 1998). ${ }^{7}$ In order to resolve the endogeneity problem, usually General Methods of Moments (GMM) or the more efficient system GMM estimators (Arellano \& Bond, 1991, and Blundell \& Bond, 1998) are among the most popular approaches. The system GMM estimator controls for the presence of unobserved firm-specific effects and for the endogeneity of the current-dated explanatory variables. It uses equations in first-differences, from which the firm-specific effects are eliminated by transformation, and for which endogenous variables lagged two or more periods will be valid instruments provided there is no serial correlation in the time-varying component of the error terms. These differenced equations are combined with equations in levels, for which the instruments must be orthogonal to the firm-specific effects. Blundell and Bond (1998) show that in autoregressive-distributive lag models, first-differences of the series can be uncorrelated with the firm-specific effects provided that the series have stationary means. We use the Blundell-Bond system GMM approach and specify our model (2) as a dynamic augmented production function in which different input decisions in the past - contained in the $\alpha_{i}$ term in equation (2) above - may affect total factor productivity (TFP).

Alternatively, many studies applied the two-step approach that is incorporated conceptually in specification (3). In the first step we apply the estimation algorithm of Levinsohn and Petrin (2003). Based on their procedure, we calculate TFP as the residual from the production function for each sector separately, taking into account that technology can differ between sectors. ${ }^{8}$ The second step is to regress TFP on sector-level controls and our targeting measures as specified in (3). ${ }^{9}$ 


\section{DESCRIPTION OF SAMPLE AND DATA}

The dataset contains the 1998-2012 annual data for virtually all Slovene firms with more than 5 employees operating in extraction, manufacturing and service sectors. Firm-year balance sheets for virtually all firms with more than 5 employees were acquired from the Agency of the Republic of Slovenia for Public Legal Records and Related Services (hereinafter: AJPES), while the Ministry of Finance provided a complete set of data on subsidies being granted in the period of study. It needs to be mentioned that financial institutions were excluded from our analysis.

Table 1 represents the descriptive statistics for 277,491 firm-year observations. ${ }^{10}$ An average firm in our sample in the period of 1998-2012 had 33 employees and generated $19,768 €$ of value added per employee. The median firm was substantially smaller and employed 7 workers and generated $13,714 €$ of value added per worker. The average firm employed 16 percent less workers in 2012 when compared to the average firm in 1997. Labor productivity per employee, on the other hand, increased during the period of observation till 2009, thereafter it dropped in 2010, increased in 2011 and again decreased in 2012. In 2012 average labor productivity was 3.31

(1) TABLE 1

Summary statistics for sampled firms in the period of 1998-2012 times higher in real terms when compared to productivity in 1998, indicating a 5.7 percent annual increase on average in the period under study.

\begin{tabular}{|c|c|c|c|c|c|c|c|}
\hline \multirow[b]{2}{*}{ Year } & \multirow[b]{2}{*}{$N$} & \multicolumn{2}{|c|}{$\begin{array}{r}\text { Value added } \\
\text { per employee }\end{array}$} & \multicolumn{2}{|c|}{$\begin{array}{l}\text { Number of } \\
\text { employees }\end{array}$} & \multicolumn{2}{|c|}{ All subsidies } \\
\hline & & Mean & Median & Mean & Median & Mean & $\overline{\text { Median }}$ \\
\hline 1998 & 11,347 & 10,103 & 7,717 & 37 & 7 & 3,234 & 0 \\
\hline 1999 & 11,130 & 11,894 & 9,031 & 38 & 7 & 7,491 & 0 \\
\hline 2000 & 11,061 & 12,421 & 9,897 & 39 & 8 & 4,559 & 0 \\
\hline 2001 & 11,346 & 14,767 & 11,160 & 32 & 6 & 10,136 & 0 \\
\hline 2002 & 11,436 & 16,100 & 12,494 & 34 & 7 & 6,824 & 0 \\
\hline 2003 & 11,535 & 17,373 & 14,143 & 35 & 7 & 10,921 & 0 \\
\hline 2004 & 11,829 & 21,198 & 15,633 & 34 & 8 & 12,670 & 0 \\
\hline 2005 & 12,305 & 23,033 & 16,659 & 32 & 7 & 8,161 & 0 \\
\hline 2006 & 12,850 & 24,738 & 17,948 & 31 & 7 & 8,956 & 0 \\
\hline 2007 & 13,794 & 25,443 & 19,755 & 29 & 7 & 7,699 & 0 \\
\hline 2008 & 14,934 & 25,241 & 21,426 & 27 & 6 & 9,206 & 0 \\
\hline 2009 & 13,589 & 31,733 & 21,682 & 29 & 8 & 17,417 & 0 \\
\hline 2010 & 13,030 & 29,214 & 23,184 & 29 & 8 & 17,976 & 0 \\
\hline 2011 & 12,462 & 35,626 & 24,834 & 30 & 8 & 21,603 & 0 \\
\hline 2012 & 11,697 & 33,460 & 25,611 & 31 & 9 & 26,852 & 0 \\
\hline
\end{tabular}

Note: All monetary data are reported in constant prices, in 2012 EUR.

Source: AJPES (2013), Ministry of Finance (2013). 
(1) TABLE 2 Summary statistics for subsample of subsidized firms in the period of 1998-2012
Subsidized firms were bigger and on average employed 91 employees with $21,574 €$ of value added per worker (see Table 2). The average subsidy in the period of 1998-2012 amounted to $78,025 €$ with median value being substantially smaller $(3,454 €)$. During the observed years, the average number of employees in our sample remained relatively unchanged until 2008.

\begin{tabular}{|c|c|c|c|c|c|c|c|}
\hline \multirow[b]{2}{*}{ Year } & \multirow[b]{2}{*}{$N$} & \multicolumn{2}{|c|}{$\begin{array}{r}\text { Value added } \\
\text { per employee }\end{array}$} & \multicolumn{2}{|c|}{$\begin{array}{l}\text { Number of } \\
\text { employees }\end{array}$} & \multicolumn{2}{|c|}{ All subsidies } \\
\hline & & Mean & Median & $\overline{\text { Mean }}$ & Median & $\overline{\text { Mean }}$ & Median \\
\hline 1998 & 1,485 & 9,654 & 8,004 & 133 & 23 & 37,324 & 1,243 \\
\hline 1999 & 2,708 & 11,797 & 9,674 & 93 & 17 & 45,327 & 1,482 \\
\hline 2000 & 2,769 & 13,778 & 10,187 & 88 & 16 & 25,467 & 1,753 \\
\hline 2001 & 2,637 & 13,479 & 11,326 & 75 & 13 & 53,093 & 1,844 \\
\hline 2002 & 2,654 & 14,888 & 12,623 & 74 & 12 & 33,321 & 1,480 \\
\hline 2003 & 2,571 & 18,127 & 14,469 & 75 & 13 & 54,114 & 1,652 \\
\hline 2004 & 1,819 & 18,456 & 15,446 & 111 & 22 & 89,090 & 4,222 \\
\hline 2005 & 1,938 & 21,716 & 17,290 & 96 & 19 & 57,029 & 2,660 \\
\hline 2006 & 2,072 & 22,775 & 18,754 & 90 & 17 & 62,034 & 2,501 \\
\hline 2007 & 1,891 & 28,770 & 22,003 & 100 & 18 & 64,395 & 2,314 \\
\hline 2008 & 1,271 & 35,585 & 26,289 & 108 & 19 & 126,879 & 5,347 \\
\hline 2009 & 1,950 & 30,020 & 23,868 & 83 & 18 & 134,499 & 4,693 \\
\hline 2010 & 1,895 & 30,955 & 24,945 & 91 & 19 & 135,155 & 7,697 \\
\hline 2011 & 1,741 & 35,820 & 27,539 & 90 & 18 & 166,783 & 11,765 \\
\hline 2012 & 1,912 & 35,254 & 27,814 & 94 & 20 & 174,077 & 13,107 \\
\hline
\end{tabular}

Note: All monetary data are reported in constant prices, in 2012 EUR.

Source: AJPES (2013), Ministry of Finance (2013).

As already mentioned, in the second section we can observe a decreasing trend of state aid in the period under study. As being reported in Table 3, in the observed period 31,529 firms with more than 5 employees in 1998 were subsidized with more than 2,460 million $€$ of total subsidies allocated excluding agriculture and fishing. Two thirds of the subsidies to firms were allocated as employment subsidies with an average of $40,914 €$ in constant prices (2012). The second group represents subsidies for research and development (R\&D), export subsidies and other subsidies being classified as revenue enhancing subsidies. The average amount of these subsidies allocated was higher compared to the first group and an average firm received 58,198 $€$ during the period under consideration. However, we observe different dynamics compared to the first group. The number of firms that received R\&D or export subsidies increased till 2005 and decreased thereafter. On the other hand, the average subsidy showed no clear pattern until 2008 and increased significantly in the period of financial crises (2009-2012). The third group of subsidies was given 
DRUŠ. ISTRAŽ. ZAGREB GOD. 27 (2018), BR. 2, STR. 199-220

DOMADENIK, P., KOMAN, M., PRAŠNIKAR, J.: DO GOVERNMENTAL...

(1) TABLE 3

Summary statistics for groups of subsidies allocated in the period of 1998-2012 mostly to firms in difficulties either related with restructuring in the nineties or severe problems during the economic downturn in the period of 2008-2012. Although the third group of subsidies represents only a small fraction of the total number of subsidies allocated since 1998 (3.8 percent), the average subsidy amounted to $425,315 €$, capturing 21 percent of total subsidies during the period of study. The fourth group of subsidies represents the subsidies for purposes not included in the first three groups (7 percent of total sample). The average subsidy amounted to $366,070 €$ but we have to mention that this high average was mostly driven by high subsidies to the Slovene railway company during this period.

\begin{tabular}{lrrrrrrrr}
\hline & \multicolumn{2}{c}{$\begin{array}{c}\text { Subsidies for employ- } \\
\text { ment and training }\end{array}$} & \multicolumn{2}{c}{$\begin{array}{c}\text { Subsidies for export } \\
\text { and R\&D activities }\end{array}$} & \multicolumn{2}{c}{$\begin{array}{c}\text { Subsidies to help } \\
\text { firms in difficulties }\end{array}$} & \multicolumn{2}{c}{ Other subsidies } \\
Year & $N$ & Mean & $N$ & Mean & $N$ & Mean & $N$ & Mean \\
\hline 1998 & 712 & 15.420 & 822 & 10.462 & 80 & 383.013 & 191 & 31.940 \\
1999 & 2171 & 15.222 & 909 & 29.144 & 143 & 234.027 & 190 & 160.339 \\
2000 & 2349 & 13.803 & 600 & 29.368 & 106 & 162.636 & 258 & 14.408 \\
2001 & 2211 & 7.732 & 539 & 29.453 & 85 & 332.582 & 168 & 468.765 \\
2002 & 2127 & 4.585 & 726 & 60.240 & 43 & 342.741 & 142 & 144.896 \\
2003 & 1635 & 7.536 & 1238 & 35.515 & 53 & 934.465 & 75 & 453.537 \\
2004 & 985 & 21.852 & 1025 & 30.402 & 48 & 1.616 .820 & 62 & 530.947 \\
2005 & 894 & 44.398 & 1232 & 21.271 & 11 & 1.073 .102 & 95 & 353.887 \\
2006 & 1325 & 32.274 & 932 & 34.101 & 11 & 1.452 .549 & 78 & 497.665 \\
2007 & 1260 & 29.995 & 807 & 32.800 & 15 & 1.062 .027 & 75 & 568.107 \\
2008 & 529 & 122.369 & 834 & 36.500 & 10 & 1.730 .266 & 85 & 597.830 \\
2009 & 973 & 82.597 & 964 & 63.753 & 269 & 118.399 & 200 & 447.314 \\
2010 & 1158 & 65.353 & 645 & 153.750 & 314 & 80.783 & 239 & 243.972 \\
2011 & 1080 & 110.100 & 758 & 113.897 & 22 & 588.939 & 280 & 269.063 \\
2012 & 1370 & 103.781 & 674 & 119.908 & 6 & 1.165 .414 & 124 & 851.850 \\
Total & 20.779 & 35.577 & 12.700 & 49.596 & 1.214 & 321.052 & 2.262 & 309.966 \\
& & & & & & & & \\
\hline
\end{tabular}

Note: All data are reported in constant prices, in 2012 EUR.

Source: Ministry of Finance (2013).

\section{EMPIRICAL RESULTS}

In Table 4, we present the estimated coefficients applying system GMM and the Levinsohn-Petrin procedure as specified in (2) and (3) in the whole period under study. To the extent that greater dispersion of subsidies within a sector induces greater focus by encouraging more firms to innovate within a specific sector, we would expect the coefficient on COMPHERF_subsidy to be positive. In all specifications in Table 4 the coefficient is positive and also very significant when we apply the two-step procedure and control for firm fixed effects. The estimated coefficients indicate that one standard deviation increase in the variable (dispersion of subsidies within the sector) leads to an increase in total factor productivity (TFP) by 0.02 per- 
DRUŠ. ISTRAŽ. ZAGREB GOD. 27 (2018), BR. 2, STR. $199-220$

DOMADENIK, P., KOMAN M., PRAŠNIKAR, J.: DO GOVERNMENTAL..

(1) TABLE 4

Estimation of empirical model for the whole period (1998-2012) centage points (or 0.03 percentage points if we don't control for firm's fixed effects). The effect is miniscule but highly significant. Therefore, we can find support for hypothesis 1c. If we observe the effect at the level of selected sectors ${ }^{11}$ (reported in Table A2 in the appendix), the effect became insignificant in the case of one-step estimation (specification 2), but remains highly significant and larger in the case of specification 3.

The coefficient on the subsidy variable (Ratio Subsidy) is negative and significant in all specifications. Subsidized firms were less productive and the difference is even larger if we control firms' fixed effects (column 3 vs column 2). The finding that more subsidized firms (if compared with total sales) exhibited lower value added than their less subsidized peers with the effect being of similar magnitude as in the two-step approach has also been confirmed in the system GMM approach (column 1). Therefore, we can find support for hypothesis $2 \mathrm{a}$. Moreover, the hypothesis was confirmed also in all specifications in the case of selected and most subsidized sectors 3 and 4 (reported in Table A2 in the appendix).

\begin{tabular}{|c|c|c|c|}
\hline & & Levins & $\begin{array}{l}\text { Petrin procedure } \\
\text { (Specification } 3 \text { ) }\end{array}$ \\
\hline System g & $\begin{array}{l}\text { thod of moments } \\
\text { (Specification } 2)^{12}\end{array}$ & Pooled OLS & $\begin{array}{l}\text { Panel fixed } \\
\text { effect estimator }\end{array}$ \\
\hline & & 2 & 3 \\
\hline Dependent variable & In value added & $\ln$ TFP & $\ln \mathrm{TFP}$ \\
\hline COMPHERF_Subsidy & $0.0002^{* *}$ & $0.0003^{* * *}$ & $0.0002^{* * *}$ \\
\hline & $(0.0000)$ & $(0.0002)$ & $(0.0000)$ \\
\hline Ratio_Subsidy & $-0.232^{* *}$ & $-0.193^{* * *}$ & $-0.238^{* * *}$ \\
\hline & (0.1043) & $(0.028)$ & $(0.013)$ \\
\hline COMP & $0.0000^{*}$ & 0.0000 & 0.000 \\
\hline & $(0.0000)$ & $(0.0000)$ & $(0.0000)$ \\
\hline LOSS & $-0.443^{* * *}$ & $-0.452^{* * *}$ & $-0.243^{* * *}$ \\
\hline & $(0.013)$ & $(0.007)$ & (0.003) \\
\hline Constant & $1.156^{* * *}$ & $8.624^{* * *}$ & $8.508^{* * *}$ \\
\hline & $(0.150)$ & $(0.016)$ & $(0.055)$ \\
\hline Year dummies & Yes & Yes & Yes \\
\hline Sector dummies & Yes & Yes & Yes \\
\hline Observations & 88,991 & 92,237 & 92,237 \\
\hline$R^{2}$ & / & 0.743 & 0.717 \\
\hline Hansen test & 44.96 & / & I \\
\hline of overid. restrictions & (p-value: 0.1202 ) & & \\
\hline
\end{tabular}

Notes: Robust standard errors are presented in parentheses.

* significant at 10 percent level; ${ }^{* *}$ significant at 5 percent level; ${ }^{* *}$ significant at 1 percent level TFP - measures total factor productivity calculated using Levinsohn-Petrin procedure COMPHERF_Subsidy - measures the degree of sectoral dispersion of subsidies Ratio Subsidy - amount of subsidy divided by sales COMP - measures the importance of markup relative to the firm's total value added LOSS - dummy variable that indicates whether zero or negative profits were reported Source: Ministry of Finance (2013), AJPES(2013). 
In order to identify how the game changed according to different institutional settings and with the outbreak of finan-

(1) TABLE 5

Estimation of empirical model in three different periods cial crises, we estimate both specifications in three different sub-periods: before joining the EU (1998-2002), in the period of high growth (2003-2008) and severe contraction (2009-2012).

\begin{tabular}{|c|c|c|c|c|c|c|}
\hline \multirow{5}{*}{$\begin{array}{l}\text { Specification: } \\
\text { Panel fixed } \\
\text { effect estimator: } \\
\text { Dependent variable }\end{array}$} & \multicolumn{2}{|r|}{ 1998-2002 } & \multicolumn{2}{|r|}{ 2003-2008 } & \multicolumn{2}{|r|}{ 2009-2012 } \\
\hline & $\begin{array}{r}\text { System } \\
\text { general } \\
\text { method of } \\
\text { movements }\end{array}$ & $\begin{array}{l}\text { Levinsohn- } \\
\text {-Petrin } \\
\text { procedure }\end{array}$ & $\begin{array}{r}\text { System } \\
\text { general } \\
\text { method of } \\
\text { movements }\end{array}$ & $\begin{array}{l}\text { Levinsohn- } \\
\text {-Petrin } \\
\text { procedure }\end{array}$ & $\begin{array}{r}\text { System } \\
\text { general } \\
\text { method of } \\
\text { movements }\end{array}$ & $\begin{array}{r}\text { Levinsohn- } \\
\text {-Petrin } \\
\text { procedure }\end{array}$ \\
\hline & 2 & 3 & 2 & 3 & 2 & 3 \\
\hline & $\begin{array}{r}-1 \ln \text { value } \\
\text { added }\end{array}$ & $-2 \ln \mathrm{TFP}$ & $\begin{array}{r}-3 \ln \text { value } \\
\text { added }\end{array}$ & $-4 \ln \mathrm{TFP}$ & $\begin{array}{r}-5 \ln \text { value } \\
\text { added }\end{array}$ & $-6 \ln \mathrm{TFP}$ \\
\hline & & & & & & \\
\hline COMPHERF_Subsidy & $\begin{array}{l}0.0000 \\
(0.000)\end{array}$ & $\begin{array}{r}-0.0004^{* * *} \\
(0.000)\end{array}$ & $\begin{array}{r}0.0001 \\
(0.0001)\end{array}$ & $\begin{array}{r}-0.0003^{* *} \\
(0.0001)\end{array}$ & $\begin{array}{r}0.001 \\
(0.0003)\end{array}$ & $\begin{array}{r}0.0003^{* * *} \\
(0.0000)\end{array}$ \\
\hline Ratio_Subsidy & $\begin{array}{r}-0.106 \\
(0.066)\end{array}$ & $\begin{array}{r}-0.209^{* * *} \\
(0.013)\end{array}$ & $\begin{array}{r}-0.248^{* *} \\
(0.122)\end{array}$ & $\begin{array}{r}-0.174^{* * *} \\
(0.024)\end{array}$ & $\begin{array}{r}-0.500^{* * *} \\
(0.1421)\end{array}$ & $\begin{array}{r}-0.193^{* * *} \\
(0.035)\end{array}$ \\
\hline COMP & $\begin{array}{r}0.000 \\
(0.000)\end{array}$ & $\begin{array}{r}0.000^{* * *} \\
(0.0000)\end{array}$ & $\begin{array}{r}0.0000^{* *} \\
(0.0000)\end{array}$ & $\begin{array}{r}0.0000 \\
(0.0000)\end{array}$ & $\begin{array}{r}0.0000 \\
(0.0000)\end{array}$ & $\begin{array}{r}0.0000 \\
(0.0000)\end{array}$ \\
\hline LOSS & $\begin{array}{r}-0.413^{* * *} \\
(0.050)\end{array}$ & $\begin{array}{r}-0.161^{* * *} \\
(0.005)\end{array}$ & $\begin{array}{r}-0.410^{* * *} \\
(0.018)\end{array}$ & $\begin{array}{r}-0.173^{* * *} \\
(0.005)\end{array}$ & $\begin{array}{r}-0.476^{* * *} \\
(0.020)\end{array}$ & $\begin{array}{r}-0.185^{* * *} \\
(0.005)\end{array}$ \\
\hline Constant & $\begin{array}{r}1.126^{* * *} \\
(0.299)\end{array}$ & $\begin{array}{r}8.342^{* * *} \\
(0.043)\end{array}$ & $\begin{array}{r}1.794^{* * *} \\
(0.188)\end{array}$ & $\begin{array}{r}9.183^{* * *} \\
(0.004)\end{array}$ & $\begin{array}{l}0.188^{*} \\
(0.097)\end{array}$ & $\begin{array}{r}9.149^{* * *} \\
(0.004)\end{array}$ \\
\hline Year dummies & Yes & Yes & Yes & Yes & Yes & Yes \\
\hline Sector dummies & Yes & Yes & Yes & Yes & Yes & Yes \\
\hline Observations & 30,004 & 31,039 & 36,04 & 37,254 & 22,254 & 16,864 \\
\hline$R^{2}$ & / & 0.699 & I & 0.245 & / & 0.253 \\
\hline $\begin{array}{l}\text { Hansen test of } \\
\text { overid. restrictions }\end{array}$ & 2.20 & / & 27.20 & / & 2.57 & / \\
\hline$p$-value & 0.8081 & I & 0.3134 & / & 0.7534 & / \\
\hline
\end{tabular}

Notes: Robust standard errors are presented in parentheses.

${ }^{*}$ significant at 10 percent level; ${ }^{* *}$ significant at 5 percent level; ${ }^{* * *}$ significant at 1 percent level

TFP - measures total factor productivity calculated using Levinsohn-Petrin procedure

COMPHERF_Subsidy - measures the degree of sectoral dispersion of subsidies

Ratio_Subsidy - amount of subsidy divided by sales

COMP - measures the importance of markup relative to the firm's total value added

LOSS - dummy variable that indicates whether zero or negative profits were reported

Source: Ministry of Finance (2013), AJPES (2013).

In the period before 2008, there is an indication that higher dispersion of subsidies in a particular sector negatively affected total factor productivity, although the coefficient was insignificant in the case of System GMM estimation. However, we can 
DRUŠ. ISTRAŽ. ZAGREB GOD. 27 (2018), BR. 2

DOMADENIK, P., KOMAN M., PRAŠNIKAR, J.: DO GOVERNMENTAL.. STR. 199-220

find support to confirm hypothesis 1c in the period 2009-2012. Interestingly, the positive effect of subsidies' allocation on total productivity is the biggest in the period of recession and similar in both specifications, indicating that the design of the instrument (targeting) is very important during the crisis. More dispersed subsidies may have a better reach to all firms that needed financial support during the financial storm. On the other hand, we can assign negative coefficient during boom time to the fact that targeting doesn't work in cases where a firm is able to reap the cost gains from exploiting scale economies. After joining the EU in 2004, Slovenian firms in manufacturing enjoyed the scale economies based on the internal market of EU Member States.

A persistently negative and statistically significant coefficient on the ratio between subsidy being granted to individual firm to its sales revenues indicates that subsidized firms exhibited lower total factor productivity when compared with less subsidized or unsubsidized firms. In the case of system GMM, the difference is even bigger. It is interesting that the productivity difference between subsidized and less or nonsubsidized firms increased during the bust period regardless of specification. However, in all three sub-periods we can find support for hypothesis $2 \mathrm{a} .{ }^{13}$

\section{DISCUSSION AND CONCLUDING THOUGHTS}

The topic of industrial policy has generated a huge debate between academics and policy advisors in the past. Although many researchers have tried to model a simple solution, the topic seems to be too broad to easily answer the main question: "Is industrial policy needed for the successful development of the country?" On one side, Stiglitz and Greenwald (2014) claim that the capital market on its own is inefficient at allocating resources towards new, growth-enhancing sectors. Therefore, state intervention is needed in order to speed up the development and sectoral diversification and to stimulate growth. Their critics (Spector et al., 2009, among others), however, argue that competition and intense rivalry between firms are far better engines of growth since government intervention is frequently connected with politicized governance, which influences and distorts the competition, and exposes it to capture by vested interests. There is also a middle ground, presented by Aghion et al. (2011), which claim that the two seemingly opposing policies should be designed in a way that they complement each other.

This study adds to the above debate by contributing to 
DRUŠ. ISTRAŽ. ZAGREB GOD. 27 (2018), BR. 2, STR. 199-220

DOMADENIK, P., KOMAN M., PRAŠNIKAR, J.: DO GOVERNMENTAL. using detailed accounting data matched with a complete set of data on subsidies over the period of 15 years. Our contribution is multi-faceted. First, in case of financial crises the industrial policy and especially state aid policy needs to be run differently than in normal times. The reasons for this are: a) in times of financial crises the criteria why some firms go bankrupt and others don't is distorted (Stiglitz \& Greenwald, 2014) and b) during financial crises some countries (USA, China, and Australia) implemented generous (pragmatic) industrial policy, related with state aid and lifelines to business sectors. The European Union, on the other hand, reacted differently and remained firm and true to its principles. As pointed out by Bole et al. (2014), state spending crisis measures were almost five times lower in the EU when compared with the US and six times lower when compared to Australia during the period 2009-2010. This could partly explain the considerably weaker post-crisis macroeconomic performance of the EU, especially relative to the US and Australia. Second, our results are similar to those reported in Aghion et al. (2015) showing that higher sectoral dispersion of subsidies increases productivity growth. Dispersion of subsidies has a positive effect on productivity in the period of economic downturn where an increase in dispersion by one standard deviation increases total factor productivity by 0.03 percentage points on average, ceteris paribus. However, we might be aware that miniscule effects are driven by the fact that in a smaller economy one is concerned more with encouraging greater focus and rivalry while allowing firms to reap the benefits of scale economies. ${ }^{14}$ Therefore, research exploring the implementation of state aid schemes and the effects of different types of subsidies on productivity remains a challenge for the future. It would be interesting to know if $R \& D$ subsidies have a substantially more pronounced positive effect on productivity as well as other different types of subsidies.

\section{ACKNOWLEDGEMENTS}

The authors would like to thank the participants of the American Economic Association and Association for Comparative Economic Studies annual meeting that was held in Boston on January 3-5, 2015, participants of the 11th International Conference Challenges of Europe: Growth, Competitiveness and Inequality that was held in Hvar on May 27-29, 2015 and two anonymous reviewers, for their valuable comments. A special thanks goes to Paul Wachtel for his suggestions on how to improve the study.

Authors' research in this study was in part supported by the Slovenian Research Agency's grants no. J5-8231, J5-2227, J5-5536, J5-4169, P5-0128. 
${ }^{1}$ Krueger and Tuncer (1982) analyzed the effects of industrial policy in Turkey in the 60s, and "show" that firms or industries not protected by tariff measures were characterized by higher productivity in growth rates than protected industries.

2 The concept of the soft budget constraint (SBC), as introduced in the context of socialist economies (Kornai, 1986), refers to the phenomenon that socialist firms are bailed out persistently by state agencies when revenues do not cover costs.

3 Special conditions mostly refer to the aid having a social character (granted to individual consumer), aid to repair the damage caused by natural disasters or aid granted to promote economic development of underdeveloped areas, execution of important projects or to remedy a serious disturbance in the economy of a Member State, aid to facilitate the development of certain economic activities or of certain economic areas as well as aid to promote culture and heritage conservation. If, after giving notice to the parties concerned to submit their comments, the Commission finds that aid granted by a State or through State resources is not compatible with the regulation or that such aid is being misused, it shall decide that the State concerned shall abolish or alter such aid within a period of time to be determined by the Commission (Article 108, Lisbon Treaty). For details see European Commission (2013).

4 The "de minimis" rule was introduced in order to exempt small aid amounts. It sets a ceiling below which aid is deemed not to fall within the scope of Article 107. In order to prevent any abuse, the regulation applies to transparent de minimis aid. However, with the outbreak of financial crises the conditions and receiving amounts for state aid have been relaxed. The initial ceiling, when the de minimis rule was first introduced in 2001, was set at EUR 100.000, but Commission Regulation No1998/2006 of December 2006 extended its scope and doubled the de minimis ceiling to EUR 200.000 granted over a period of three years, as it is not regarded as state aid within the meaning of Article 107.

5 This argument is in favor of "infant industry" protection.

${ }^{6}$ Her_subsidy $_{j t}=\sum_{i \in j}\left(\text { Subsidyi }_{j t} / \text { Sum_subsidy }{ }_{j t}\right)^{2}$

7 See also Harris and Moffat (2015).

8 The results of first stage are reported in Table A1 in the Appendix.

9 If we regress firm-level measures of productivity on these sectoral dispersion measures, we might encounter problems related with potential endogeneity issues. If the government, for example, favors large and more successful firms to be subsidized, then a firm that accounts for a large share of subsidies within a sector might also exhibit higher labor productivity reflecting spurious relationships between subsidies and performance. A similar but downward bias of coefficient estimation would exist if the government opted for supporting firms in difficulties.

10 The data were cleaned and outliers were dropped. So we ended up with an unbalanced panel of 277,491 firm-year observations. All monetary values are expressed in constant prices, in 2012 EUR. We used 
DRUŠ. ISTRAŽ. ZAGREB GOD. 27 (2018), BR. 2, STR. 199-220

DOMADENIK, P., KOMAN M., PRAŠNIKAR, J.: DO GOVERNMENTAL. consumer price index as a deflator, and we transformed monetary values prior to 2007, which were expressed in SIT, into EUR, using the conversion factor 1 EUR $=239.640$.

11 We report estimations for three most subsidized sectors in our sample of firms. These sectors are: sector 3 that includes manufacturing of chemicals, pharmaceutical products, rubber, plastics, ceramics, metals, metal products, sector 4 that includes manufacturing of computers, machines, vehicles and sector 11 that includes firms in information communication technology. In the period 1998-2012 firms in sector 3 received $13 \%$ of all subsidies, firms in sector 4 received $19 \%$ of all subsidies, while firms in sector 11 received $15 \%$ of all subsidies. Our initial set of data consists of 13 different sectors and an interested reader could get full estimations upon request.

12 Due to page limitations we only report coefficients for the selected variables. Full estimation can be obtained upon request.

13 Due to similar results at the level of particular sectors in the complete time span, we don't provide results for selected sectors in all three sub-periods. However, estimations could be obtained upon request. 14 Smaller economies like South Korea forced firms that received targeted support to compete on global markets in order to exploit the benefits of competition (Aghion et al., 2015).

\section{APPENDIX}

(1) TABLE Al

Estimation of production function by sectors using Levinsohn-Petrin algorithm

\begin{tabular}{|c|c|c|c|c|c|c|c|}
\hline \multirow[b]{2}{*}{ sector } & \multicolumn{2}{|l|}{ ln (labor) } & \multicolumn{2}{|l|}{$\underline{\ln \text { (capital) }}$} & \multicolumn{2}{|c|}{$\underline{\ln (\text { material cost) }}$} & \multirow[b]{2}{*}{ observations } \\
\hline & coefficient & se & coefficient & se & coefficient & se & \\
\hline (1) & $0.202^{* * *}$ & $(0.015)$ & $0.027^{* * *}$ & (0.008) & $0.300^{* * *}$ & (0.105) & 5,286 \\
\hline (2) & $0.241^{* * *}$ & $(0.028)$ & 0.021 & $(0.017)$ & $0.246^{*}$ & (0.128) & 1,740 \\
\hline (3) & $0.170^{* * *}$ & $(0.017)$ & 0.013 & $(0.010)$ & $0.411^{* * *}$ & (0.158) & 8,071 \\
\hline (4) & $0.174^{* * *}$ & $(0.010)$ & $0.034^{* * *}$ & $(0.010)$ & 0.110 & $(0.078)$ & 12,538 \\
\hline (5) & $0.153^{* * *}$ & (0.019) & $0.063^{* * *}$ & (0.023) & 0.219 & $(0.227)$ & 1,843 \\
\hline (6) & $0.085^{* * *}$ & $(0.029)$ & 0.001 & (0.007) & 0.128 & $(0.266)$ & 1,206 \\
\hline (7) & $0.194^{* * *}$ & (0.011) & $0.025^{* *}$ & (0.011) & $0.303^{* *}$ & $(0.104)$ & 8,689 \\
\hline (8) & $0.138^{* * *}$ & $(0.007)$ & $0.049^{* * *}$ & $(0.006)$ & $0.392^{* * *}$ & $(0.060)$ & 22,489 \\
\hline (9) & $0.125^{* * *}$ & (0.011) & $0.051^{* * *}$ & (0.011) & $0.417^{* * *}$ & (0.092) & 7,055 \\
\hline (10) & $0.185^{* * *}$ & $(0.018)$ & $0.023^{* *}$ & (0.011) & $0.405^{* * *}$ & $(0.119)$ & 3,364 \\
\hline (11) & $0.259^{* * *}$ & $(0.025)$ & $0.068^{* * *}$ & $(0.024)$ & 0.253 & $(0.266)$ & 5,587 \\
\hline (12) & $0.335^{* * *}$ & $(0.017)$ & $0.034^{* * *}$ & $(0.010)$ & 0.122 & (0.100) & 6,436 \\
\hline (13) & $0.308^{* * *}$ & (0.008) & 0.001 & (0.004) & $0.254^{* * *}$ & (0.067) & 19,893 \\
\hline
\end{tabular}

Notes: Standard errors in parentheses; ${ }^{* *} p<0.01,{ }^{* *} p<0.05,{ }^{*} p<0.1$.

Estimation was performed using levpet production function estimation in Stata. Option revenue was used, which indicates that the dependent variable represents gross revenues or output. The GMM estimator was used.

Source: AJPES (2013). 


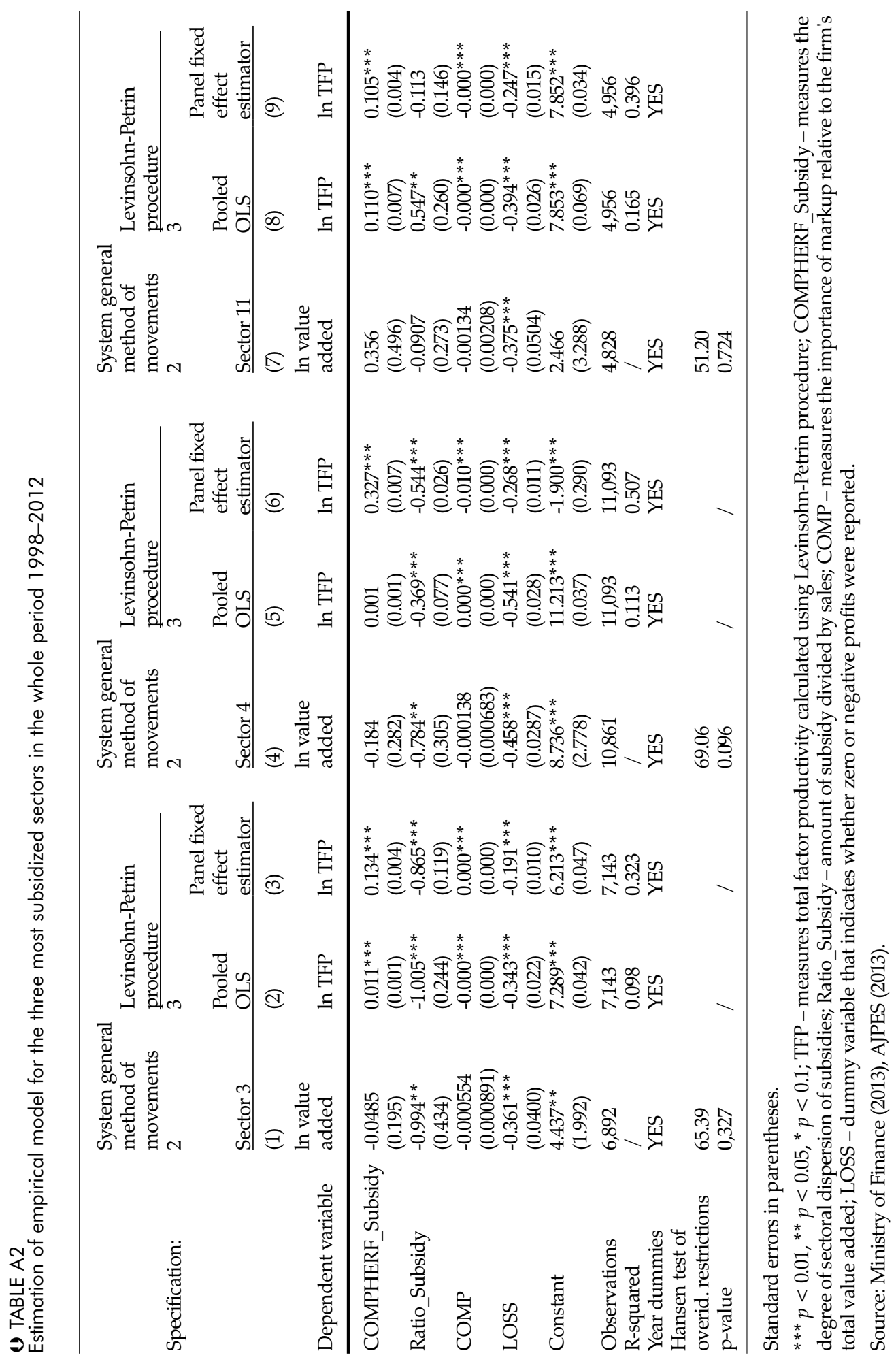


Acemoglu, D. (2009). When does labor scarcity encourage innovation? NBER Working Papers 14809, National Bureau of Economic Research, Inc.

Aghion, P., Cai, J., Dewatripoint, M., Du, L., Harrison, A., \& Legros, P. (2015). Industrial policy and competition. American Economic Journal: Macroeconomics, 7(4), 1-32. https://doi.org/10.1257/mac.20120103

Aghion, P., Boulanger, J., \& Cohen, E. (2011). Rethinking industrial policy. Bruegelpolicybrief, 4, 1-8. Available at http://bruegel.org/wpcontent/uploads/imported/publications/pb_2011-04_final.pdf

AJPES (2013). Balance sheet and profit and loss account data for Slovenian firms in the period 1998-2013. Ljubljana: Agency of the Republic of Slovenia for Public Legal Records and Related Services.

Arellano, M., \& Bond, S. R. (1991). Some tests of specification for panel data: Monte Carlo evidence and an application to employment equations. The Review of Economic Studies, 58(2), 277-297. https://doi. org $10.2307 / 2297968$

Blundell, R. W., \& Bond, S. R. (1998). Initial conditions and moment restrictions in dynamic panel data models. Journal of Econometrics, 87(1), 115-143. https://doi.org/10.1016/S0304-4076(98)00009-8

Bole, V., Gazibarić, T., Hrastel, M., Korelc, P., \& Prašnikar, J. (2014). Industrial policy in the theory and EU practice. In J. Prašnikar (Ed.), Industrial policy in retrospective (pp. 11-30). Ljubljana: Časnik Finance.

Bronzini, R., \& Iachini, E. (2014). Are incentives for R\&D effective? Evidence from a regression discontinuity approach. American Economic Journal: Economic Policy, 6(4), 100-134. https://doi.org/10.1257/pol.6.4.100

Cepec, J., Beširević, H., Černe, A., Golle, L., \& Jelen, K. (2014). Industrial policy in Slovenian market "euphoria" period (2003-2008). In J. Prašnikar (Ed.), Industrial policy in retrospective (pp. 193-217). Ljubljana: Casnik Finance.

Criscuolo, C., Martin, R., Overman, H. G., \& Van Reenen, J. (2016). The casual effects of an industrial policy. Cep Discussion Paper No. 1113.

Einiö, E. (2014). R\&D subsidies and company performance: Evidence from geographic variation in government funding based on the ERDF population-density rule. Review of Economics and Statistics, 96(4), 710-728. https://doi.org/10.1162/REST_a_00410

European Commission (2013). State aid manual of procedures internal DG competition - working documents on procedures for the application of Articles 107 and 108 TFEU. Luxembourg: Publications Office of the European Union. Available at http://ec.europa.eu/competition/state_ aid/studies_reports/sa_manproc_en.pdf

Griliches, Z., \& Mairesse, J. (1998). Production functions: The search for identification. In S. Strom (Ed.), Essays in honour of Ragnar Frisch. Econometric Society Monograph Series. Cambridge: Cambridge University Press.

Harris, R., \& Moffat, J. (2015). Plant-level determinants of total factor productivity in Great Britain, 1997-2008. Journal of Productivity Analysis, 44(1), 1-20. https://doi.org/10.1007/s11123-015-0442-2

Howell, S. (2015). Financing constraints as barriers to innovation: Evidence from RED grants to energy startups. Job market paper (working study). 
DRUŠ. ISTRAŽ. ZAGREB GOD. 27 (2018), BR. 2 STR. $199-220$

DOMADENIK, P., KOMAN, M., PRAŠNIKAR, J.: DO GOVERNMENTAL...
Jones, C. I. (1998). Introduction to economic growth. New York: W.W. Norton \& Co., Inc.

Kornai, J. (1986). The soft budget constraint. Kyklos, 39(1), 3-30. https:// doi.org/10.1111/j.1467-6435.1986.tb01252.x

Kovač, M., Breg, N., Rudl, N., Volf, M., \& Vuga, U. (2014). Industrial policy in Slovenia under the transition to the market economy (1991-2002). In J. Prašnikar (Ed.), Industrial policy in retrospective (pp. 177-193). Ljubljana: Časnik Finance.

Krueger, A. O., \& Tuncer, B. (1982). An empirical test of the infant industry argument. American Economic Review, 72(5), 1142-1153.

Levinsohn, J., \& Petrin, A. (2003). Estimating production function using inputs to control for unobservables. The Review of Economic Studies, 70(2), 317-341. https://doi.org/10.1111/1467-937X.00246

Ministry of Finance (2013). Firm level data on government subsidy allocation programs. Ljubljana: Ministry of Finance.

Nunn, N., \& Trefler, D. (2010). The structure of tariffs and long-term growth. American Economic Journal: Macroeconomics, 2(4), 158-194. https:// doi.org/10.1257/mac.2.4.158

Rodrik, D. (2007). Industrial development: Stylized facts and policies. In Industrial development for the 21st century (pp. 1-28), New York: United Nations.

Spector, D., Chapsal, A., \& Eymard, L. (2009). Competition policy, industrial policy and national champions. Competition Law and Policy, pp. 25-45. Available at http://www.oecd.org/daf/competition/445480 25.pdf

Stiglitz, J. E., \& Greenwald, B. C. (2014). Creating a learning society. A new approach to growth, development, and social progress. New York: Columbia University Press.

Takalo, T., Tanayama, T., \& Toivanen, O. (2013). Market failures and the additionality effects of public support to private R\&D: Theory and empirical implications. International Journal of Industrial Organization, 31(5), 634-642. https://doi.org/10.1016/j.ijindorg.2013.02.002

\section{Povećavaju li državne subvencije produktivnost poduzeća? Dokazi panelske analize slovenskih tvrtki}

Polona DOMADENIK, Matjaž KOMAN, Janez PRAŠNIKAR Ekonomski fakultet, Ljubliana

Naša se studija bavi istraživanjem odnosa između produktivnosti (ili rasta produktivnosti) i raspodjele državnih potpora u Sloveniji u razdoblju od 1998. do 2012. godine. Slovenija je gotovo idealan slučaj među državama, jer se iznos subvencija dodijeljenih u relevantnom razdoblju znatno smanjio nakon pristupanja EU-u. Naše istraživanje temelii se na teorijskom modelu Aghiona i sur. (2015) koji tvrdi da 
DRUŠ. ISTRAŽ. ZAGREB GOD. 27 (2018), BR. 2, STR. 199-220

DOMADENIK, P., KOMAN M., PRAŠNIKAR, J.:

DO GOVERNMENTAL. sektorska politika može poboljšati rast i učinkovitost ako se njome postiže konkurentnost. Glavni rezultati pokazuju da povećanjem raspodjele subvencija unutar pojedinih sektora za jednu standardnu devijaciju produktivnost u prosjeku raste za 0,03 postotna boda, ceteris paribus. Državne potpore posebno su bile važne u razdoblju ekonomske krize (2009-2012). Međutim, pronašli smo dokaze da su poduzeća koja su primila više subvencija bila manje produktivna u usporedbi s onima iz istoga sektora koja su primila manje subvencija ili ih nisu vopće primila. Razlika je bila najveća u razdoblju ekonomske krize.

Kliučne riječi: državne potpore, subvenciie, industriijka politika, konkurencija

\section{(c) (1) $(9)$}

Međunarodna licenca / International License:

Creative Commons Attribution-NonCommercial-NoDerivatives 4.0. 